\title{
The Effect of Fouling on the Baffle Spacing of a Shell and Tube Heat Exchanger
}

\author{
Havva CEYLAN ${ }^{* 1}$ (D) Buket ÇINAR GELI'R ${ }^{2}$ (D) \\ ${ }^{1}$ Namık Kemal University, Faculty of Engineering, Department of Mechanical Engineering, 59860, Tekirdag, \\ Turkey \\ 2Yünsa Worsted \& Woolen Production and Trading Company, Department of R\&D, 59500, Tekirdag, Turkey
}

(Alınış / Received: 22.01.2020, Kabul / Accepted: 18.09.2020, Online Yayınlanma / Published Online: 20.12.2020)

\section{Keywords}

Heat exchanger,

Baffle spacing,

Fouling

\begin{abstract}
In this study, shell-side fouling of the shell and tube heat exchanger (STHE) designed for a textile firm was examined. The economic baffle spacing was determined for clean and fouled conditions. The energy and pressure loss analysis was performed using Bell -Deleware method. To predict the fouling thickness (FT), a prototype tube bundle was installed in the chimney of the stenter machine to expose to the exhaust gases. The FT on tubes reached to about $0.5 \mathrm{~mm}$ within three months. Fuel saving (FS) due to recovered heat and fan power consumption (FPC) due to pressure drop were calculated by assuming that FT varies linearly with time. In the result of the cost analysis, it was seen that economic baffle spacing was affected by $\mathrm{R}$ value which is the ratio of unit cost of natural gas to that of electricity but the effect of fouling on the optimum baffle spacing was not significant. Fouling affected optimum baffle spacing when $\mathrm{R}$ is greater than 15 . In this study optimum baffle spacing was determined as $1.16 \mathrm{~m}$ for both fouled and clean condition, because of that $\mathrm{R}$ is 3.52 in Turkey at the time of the study.
\end{abstract}

\section{Kirlenmenin Bir Gövde-Boru Isı Eşanjörünün Şaşırtma Levhası Aralığı Üzerindeki Etkisi}

Anahtar Kelimeler

Isı değiștiricisi, Şașırtma levhası aralı̆̆ı, Kirlenme

\begin{abstract}
Özet: Bu çalışmada, bir tekstil firması için tasarlanan gövde borulu ısı eşanjörünün gövde tarafındaki kirlenmenin etkileri incelenmiş, temiz ve kirli koşullar için ekonomik şaşırtma levhası aralığı belirlenmiştir. Enerji ve basınç kaybı analizi Bell-Deleware yöntemi kullanılarak yapılmıştır. Kirlenme kalınlığını tahmin etmek için, ramöz makinesinin bacasına egzoz gazlarına maruz kalması için bir prototip boru demeti yerleştirilmiş ve üç ay içinde borulardaki kirlenme kalınlığının yaklaşık 0.5 mm'ye ulaştığı görülmüştür. Hesaplarda, kirlenme kalınlığının zamanla doğrusal olarak değiştiği varsayılmıștır. Maliyet analizi sonucunda, ekonomik şaşırtma levhası aralığının, doğal gazın birim maliyetinin elektriğin birim maliyetine oranı olan $\mathrm{R}$ değerinden etkilendiği, ancak optimum şaşırtma levhası aralığı üzerinde kirlenmenin etkisinin önemli olmadığı görülmüştür. Kirlenme, R nin 15'den büyük olduğu durumlarda optimum şaşırtma levhası aralığını etkilemiştir. Çalışmanın yapıldığı zamanda Türkiye'de R değerinin 3.52 olması nedeniyle hem kirli hem de temiz durumda optimum şaşırtma levhası aralığı $1.16 \mathrm{~m}$ olarak belirlenmiştir.
\end{abstract}

\section{Introduction}

Baffles are widely used in heat exchangers to increase the heat transfer coefficient by approaching the ideal counter flow and to prevent vibration by supporting the tubes. The reducing the distance between the baffles, which are called baffle spacing (BS), increases not only heat transfer but also pressure loss in resulting additional cost. According to this point of view, baffle spacing is an important parameter that should be considered in heat exchanger design.

In literature, some studies have mainly focused on optimum BS. Abdelkader et al. [1] examined the effect of baffle spacing, baffle cut, tube arrangement, mass flow rate and fluid properties on performance of a STHE. According the results, as the number of baffles increases, the heat transfer coefficient and pressure drop increase on the shell-side. Soltan et al. [2] 
studied the effect of BS on heat transfer area and pressure drop for segmentally baffled shell and tube condensers. Also, as a result of this research, they presented some correlation determining the optimum BS. Li et al. [3] investigated the effect of BS on the local heat transfer coefficients and pressure drop of STHE with segmental baffles. Eryener [4] determined the optimum ratio of baffle spacing to shell diameter by applying the thermoeconomic analysis method. Jozaei et al. [5] studied the effects of baffle spacing on pressure drop, heat transfer and estimated price in a STHE with single segmental baffles and staggered tubes layout in Iran, Arvand Petrochemical. They suggested the optimum baffle spacing for a sufficient heat duty, low cost and low pressure drop.

Heat exchangers tubes are coated with a fouling layer with low heat transfer coefficient over time. This layer worses heat transfer and also increases pressure loss resulted in more power consumption and money loss. Therefore, fouling has been examined in different aspects, in the literature. Most of the research are based on understanding the fouling behaviours of heat exchangers, the fouling mitigation methods and the optimal cleaning schedule. Wang et al. [6] investigated the fouling characteristics of a H-type finned tube heat exchanger. The results showed that the increase in particle diameter and inlet velocity decreases the fouling resistance. WallhauBer et al. [7] conducted an overview with fouling monitoring methods (temperature and heat transfer parameters, pressure drop, acoustic methods, electrical parameters) in heat exchangers. Kim et al. [8] investigated the effects of using filtration in physical water treatment on mitigation of mineral contamination in a double-pipe heat exchanger. Markowski et al. [9] proposed a method for defining the effect of contamination on heat recovery in a heat exchanger network. A case study for optimal cleaning scheduling on individual exchangers was presented. Shen et al. [10] investigated the effect of the installation location of a heat exchanger relative to a wastewater pump on the contamination onto the surface of bundled tubes in a STHE. In addition, various design suggestions have been made by some researchers to reduce the effects of contamination. Bouris et al. [11] was numerically studied the fouling behavior for three different tube bundle configurations on lignite utility boiler heat exchangers. The results showed that the deposition rate decreased by $73 \%$ when using elliptical tubes. Mavridou et al. [12] proposed a new heat exchanger geometry that uses tubes of different diameters in an inline arrangement to study gas side particle contamination. Han et al. [13] examined the effects of parameters such as particle diameter, flow velocity and also tube shape and arrangements on fouling rate reduction in STHEs. Results show that using both oval tubes and staggered arrangements can reduce the fouling rate. Caputo et al. [14] described the optimal design approach based on the minimization of the life cycle cost for STHE. This approach joints the optimization of both the equipment design and the cleaning policy. As seen from the article review, the number of articles on the heat exchanger design, where the effects of fouling are taken into account is relatively small. And also, heat exchanger design recommendations to reduce the fouling effects are focused on tube geometry.

This study was conducted to analyse the effect of fouling on baffle spacing. While some of above studies [1-4] did not take into account the effect of fouling on the optimum baffle spacing, Jozaei, A.F. [5] assumed a constant FT. In this study, the economic baffle spacing was determined by assuming that fouling thickness increased linearly with time.

\section{Material and Method}

\subsection{Heat exchanger design}

The mixture of combustion gas from the burner of the stenter machine, fresh air and recirculating air enters to stenter machine of the textile company and contacts the fabric. It gives heat energy to fabric and taken out of water vapor from fabric and then is exhausted to the atmosphere.

The STHE, shown schematically in Figure 1, was designed in order to utilize the heat of exhaust air from stenter. Fresh air from the factory environment flows through tubes and the exhaust air from the drying machine flows through shell side of STHE. The exchanger was designed with one-tube passes and the rotated square arrangement due to easy cleaning and its specifications were summarized in Table1.

\begin{tabular}{|c|c|c|}
\hline \multicolumn{2}{|l|}{ Specifications } & Value \\
\hline \multicolumn{2}{|l|}{ Inner tube diameter (m) } & 0.036 \\
\hline \multicolumn{2}{|l|}{ Outer tube diameter (m) } & 0.04 \\
\hline \multicolumn{2}{|c|}{$\begin{array}{l}\text { Thermal conductivity of stainless } \\
\text { steel tube wall }\left(\mathrm{k}_{\text {tube }}\right)(\mathrm{W} / \mathrm{mK})\end{array}$} & 16.2 \\
\hline Number of tubes(N) & & 365 \\
\hline Length of tube (L) (m) & & 4.65 \\
\hline Baffle cut $(\%)$ & & 30 \\
\hline Fluid properties & $\begin{array}{c}\text { Inlet } \\
\text { shell side }\end{array}$ & $\begin{array}{c}\text { Inlet tube } \\
\text { side }\end{array}$ \\
\hline$(\mathrm{T})\left({ }^{\circ} \mathrm{C}\right)$ & 150 & 30 \\
\hline Relative humidity (\%) & - & 46 \\
\hline $\begin{array}{l}\text { Absolute humidity } \\
\left(\mathrm{kg}_{\mathrm{v}} / \mathrm{kg}_{\mathrm{a}}\right)\end{array}$ & 0.08 & - \\
\hline $\begin{array}{l}\text { Volume flow } \\
\text { rate }\left(\dot{V}_{S}\right) \quad\left(\mathrm{m}^{3} / \mathrm{h}\right)\end{array}$ & 15000 & 15000 \\
\hline
\end{tabular}

\subsection{Fouling resistance}

Fouling resistance varies depending on the fouling thickness and the thermal conductivity of fouling 

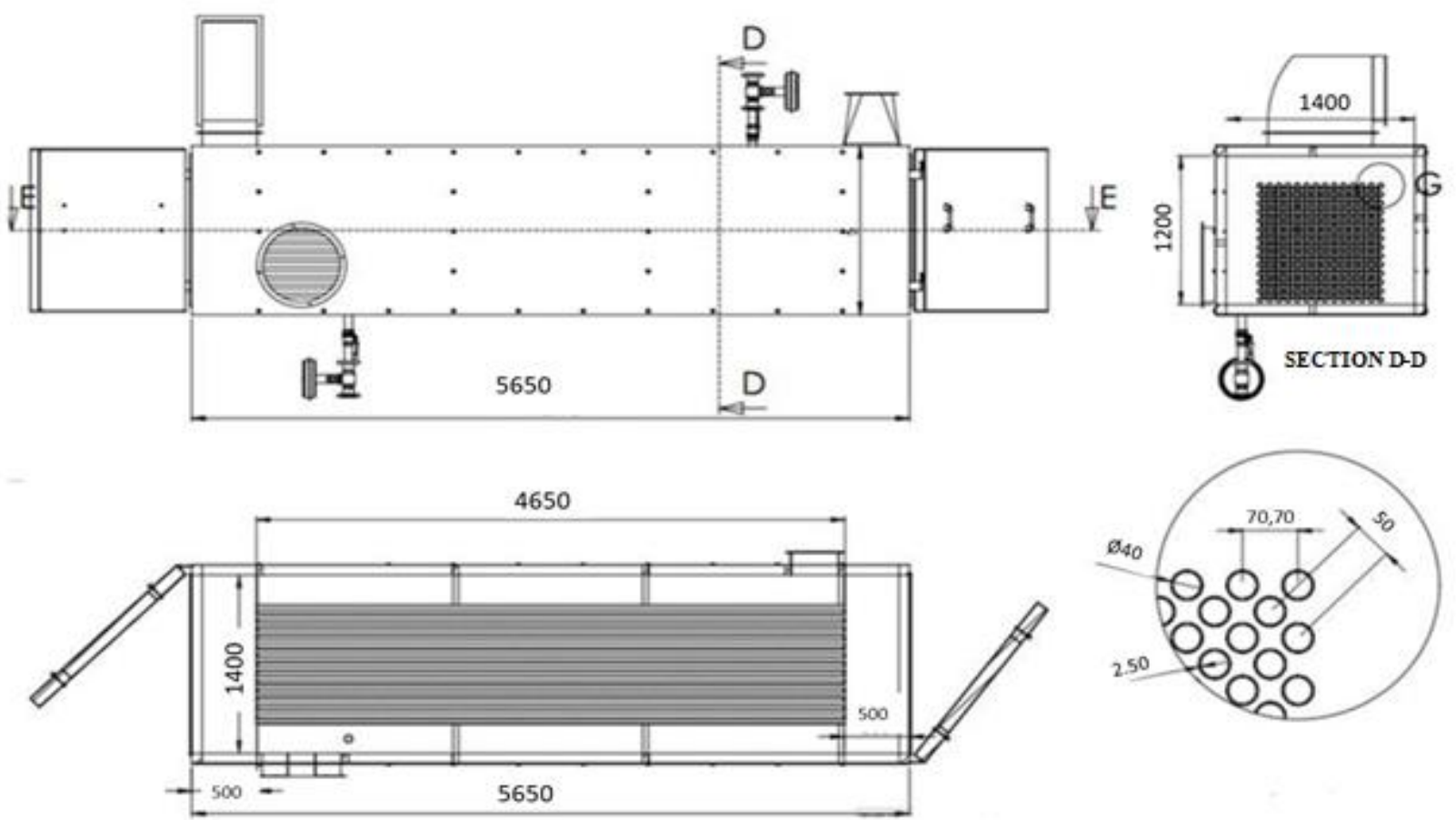

SECTIONE-E

Figure 1. Drawing of the exchanger

layer. Fouling deposition in heat exchangers depends on many variables. Therefore each system should be evaluated considering its own operating conditions. In this study, the pollutants in the exhaust gases which passes through shell side are the gaseous compounds in the flue gases generated by combustion of natural gas, some wool fragments and oil. The thermal conductivity of fouling layer was assumed to be 0.05 and $0.1 \mathrm{~W} / \mathrm{mK}$ considering these pollutants.

Additionally, a test was carried out to determine the FT. A tube bundle consisting of 100 stainless steel tubes with an outer diameter of $10 \mathrm{~mm}$ was manufactured. The distance between the tube centers is $12.5 \mathrm{~mm}$. It was mounted in the chimney of stenter machine to expose to the exhaust gases.

It was seen that fouling thickness was in the range of $0.4-0.7 \mathrm{~mm}$ at the end of three month operating period after mounting the tube bundle (Figure 2). FT was taken as $0.5 \mathrm{~mm}$ in calculations.

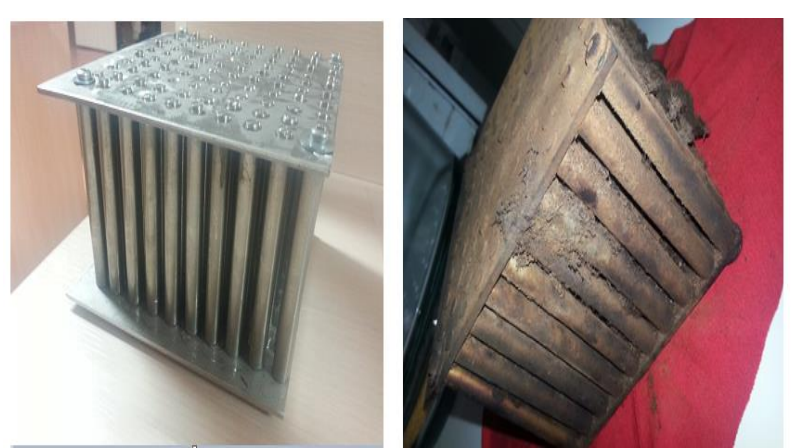

Figure 2. The photographs of the clean and fouled tubes.

\subsection{Energy analysis}

An iteration process which was summarized by the flow chart shown in Fig 3 was performed for determining the outlet temperature of tube and shell side hence recovered heat. Bell-Deleware method $[15,16]$ was used in the energy and pressure loss analysis. Bell-Delaware method is simple and reliable enough to be used in engineering applications [17]. Kern method is another proposed method for calculating shell-side pressure drop and heat transfer coefficient. However, this method is restricted to a fixed baffle cut (25\%) and cannot adequately account for baffle-to-shell and tube-to-baffle leakage [18].

Fluid passing through both sides of the exchanger was assumed as the humid air. The thermophysical properties of the humid air were determined by means of EES (Engineering Equation Solver). The shell side Reynolds Number $\left(R e_{s}\right)$ based on outside tube diameter $\left(d_{o}\right)$ is defined by Eq. 1.

$$
R e_{s}=\frac{\rho_{s} w_{s} d_{o}}{\mu_{s}}
$$

The velocity in cross flow zone, $\mathrm{w}_{\mathrm{s}}$, is defined as;

$$
w_{s}=\frac{\dot{m}_{S}}{\rho_{S} A_{s}}=\frac{\dot{m}_{S}}{\rho_{s}} \frac{1}{\left(\sqrt{2} P-d_{o}\right) B \frac{H}{\sqrt{2} P}}
$$

where $A_{s}$ is the cross flow area at the shell centerline for one cross-flow between two subsequent baffles, $P$ is the tube pitch $\left(\mathrm{P}=1.25 \mathrm{~d}_{0}\right), \mathrm{H}$ is the heat exchanger width and $B$ is the baffle spacing. The dimensionless Colburn factor $\mathrm{J}_{\mathrm{h}, \mathrm{B}}$ in the Bell-Deleware method is 
determined by Equation 3 according to the shell side Reynolds Number $\left(R e_{s}\right)$.

$$
J_{h, B}=a_{1}\left(\frac{1.33}{P / d_{o}}\right)^{y}\left(R e_{s}^{a_{2}}\right)
$$

The values of $y$ is defined as follows:

$$
y=\frac{a_{3}}{1+0.14\left(R e_{s}^{a_{4}}\right)}
$$

where, $a_{1}=0.370, a_{2}=-0.396, a_{3}=1.930, a_{4}=0.5$ for the rotated square arrangement that Re Number is in range $10^{4}-10^{5}$ [19]. Minimum and maxsimum Re Numbers of shell side are $13095(B=1,16 \mathrm{~m}$ and no fouling) and $27183\left(B=0.58 \mathrm{~m}, \delta_{\mathrm{f}}=0.05 \mathrm{~mm}\right.$ and $\left.k_{f 2}=0.1 \mathrm{~W} / \mathrm{mK}\right)$ respectively.

$F_{n}, F_{w}, F_{b}, F_{L}$ are the correction factors for the nonideal cross flow in a baffled heat exchanger. The combined effects of all these correction factors in a well-designed shell and tube exchanger is of the order of 0.6 [19].

In this study, the fouling only on the shell side was taken into account because of that the exhaust gases from the drying machine passes through shell side. The fouling thermal resistance was calculated as:

$$
R_{f}=\frac{d_{i}}{2 k_{f}} \ln \left(\frac{d_{o}+2 \delta_{f}}{d_{o}}\right) \quad\left(m^{2} K / W\right)
$$

where, $k_{f}$ and $\delta_{f}$ are the thermal conductivity and the fouling thickness respectively, $d_{i}$ and $d_{o}$ are inner and outer diameter of tubes respectively.

Heat transfer due to the change in temperature of the tube side fluid is calculated in Eq. 6 .

$$
\dot{Q}_{r}=\left(\dot{m} c_{p}\right)_{t}\left(T_{t o}-T_{t i}\right)
$$

\subsection{Pressure drop}

\subsubsection{Tube-side pressure drop}

Tube-side total pressure drop for the fully developed laminar or turbulent flow was calculated by Eq. 7 .

$$
\Delta P_{t}=\left[\lambda_{s} \frac{L}{d_{i}}+\xi_{y}\right] \frac{\rho w^{2}}{2}
$$

The sum of all local loss coefficients $\left(\xi_{y}\right)$ in the intube stream was taken as 2.5 [20]. The coefficient of friction $\lambda_{s}$, for development zone of the turbulent flow in the tube which is assumed to be smooth was calculated by Equation 8 .

$$
\lambda_{\mathrm{s}}=\frac{0.316}{\operatorname{Re}^{0.25}} \quad 10^{4}<\operatorname{Re}<2.10^{5}
$$

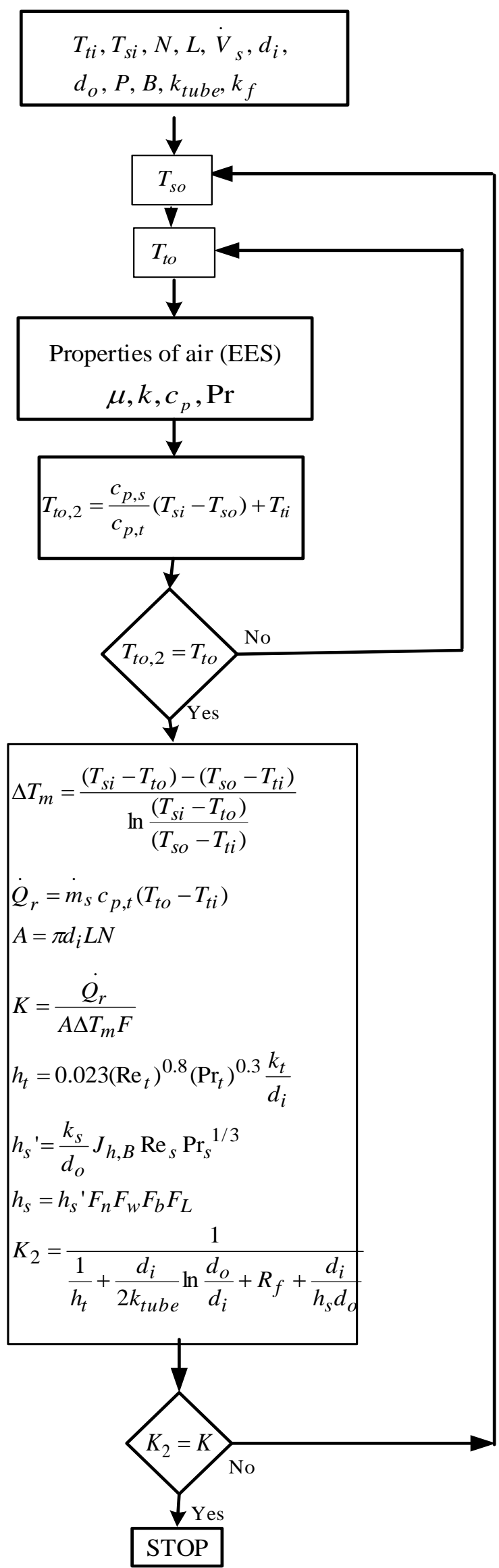

Figure 3. Energy analysis algorithm 


\subsubsection{Tube-side pressure drop}

The total shell side pressure drop, $\Delta \mathrm{P}_{\mathrm{S}}$, is the sum of three components. These are the pressure drop in the interior cross-flow sections, $\Delta \mathrm{P}_{\mathrm{b}}$, the pressure drop in the window section, $\Delta \mathrm{P}_{\mathrm{w}}$, the pressure drops at the shell entrance and exit, $\Delta \mathrm{P}_{\mathrm{e}}$. These were calculated as the following Equations.

$$
\begin{gathered}
\Delta P_{s}=\left(N_{b}-1\right) \Delta P_{b}+N_{b} \Delta P_{w}+2 \Delta P_{e} \\
\Delta P_{b}=R_{L} R_{b} \Delta P_{b, i} \\
\Delta P_{b, i}=8 J_{f} n_{c b} \frac{\rho_{s} w_{s}^{2}}{2} \\
\Delta P_{w}=R_{L}\left(2+0.6 n_{c w}\right) \frac{\rho_{s} w_{z}^{2}}{2} \\
w_{z}=\sqrt{w_{w} w_{s}}, \quad w_{w}=\frac{\dot{m}_{s}}{\rho_{s} A_{w}} \\
\Delta P_{e}=\Delta P_{b, i}\left(\frac{n_{c w}+n_{c b}}{n_{c b}}\right) R_{b}
\end{gathered}
$$

Where, $\mathrm{N}_{\mathrm{b}}$ is the number of baffles, $\Delta \mathrm{P}_{\mathrm{b}, \mathrm{i}}$ is the pressure drop for an ideal cross-flow section, $\mathrm{n}_{\mathrm{cb}}$ is the number of tube rows crossed between baffle tips, $\mathrm{n}_{\mathrm{cw}}$ is the number of tube rows crossed in the window zone, $\mathrm{w}_{\mathrm{z}}$ is geometric mean velocity, $\mathrm{w}_{\mathrm{w}}$ is window velocity, $A_{w}$ is window area, $R_{b}$ is the correction factor for bypass flow effects caused by the gap between the tube bundle and the shell inner diameter, $\mathrm{R}_{\mathrm{L}}$ is the correction factor for baffle leakage effects. Typically, $\mathrm{R}_{\mathrm{b}}$ is in a range $0.5-0.8$ and $\mathrm{R}_{\mathrm{L}}$ is in a range $0.4-0.5$ depending on the construction type [19]. In this study, for $R_{b}$ and $R_{L}$, the average values in these ranges were used. In the Bell-Deleware method, the dimensionless pressure multiplier $\mathrm{J}_{\mathrm{f}}$ is determined by Eq. 15 based on the Reynolds number of the shell side.

$$
J_{f}=b_{1}\left(\frac{1.33}{P / d_{o}}\right)^{y}\left(R e_{s}^{b_{2}}\right)
$$

The values of $y$ is defined as follows:

$$
y=\frac{b_{3}}{\left(1+0.14\left(R_{s}^{b_{4}}\right)\right)}
$$

Where, $b_{1}=0.303, b_{2}=0.126, b_{3}=6.59, b_{4}=0.52$ for the rotated square arrangement that Re Number is in range $10^{4}-10^{5}$ [19].

\subsection{Fuel saving and fan power consumption}

Fuel saving $\left(\dot{\mathrm{V}}_{\mathrm{f}}\right)$ due to recovered heat $\left(\dot{\mathrm{Q}}_{\mathrm{r}}\right)$ was calculated by Equation 17 .

$$
\dot{V}_{f}=\frac{\dot{Q}_{r}}{H_{u} \eta_{c}}\left(m^{3} / s\right)
$$

Here, $\mathrm{Hu}$ is the lower heating value of natural gas as $34485 \mathrm{~kJ} / \mathrm{m}^{3}, \eta_{c}$ is the combustion efficiency as 0.90 . The fan power consumption of tube side and shell side for overcoming friction losses were calculated by Eq.18 and Eq.19.

$$
\begin{aligned}
& \dot{W}_{t}=\frac{\dot{V}_{s} \Delta P_{t}}{\eta_{f t}} \\
& \dot{W}_{s}=\frac{\dot{V}_{s} \Delta P_{s}}{\eta_{f s}}
\end{aligned}
$$

Where, $\eta_{f t}$ and $\eta_{f s}$ are the fan efficiency of tube and shell side, respectively, $\eta_{f t}=\eta_{f s}=0.85, \dot{V}_{s}$ is the volume flow rate of humid air in both tube and shell side.

By assuming that FT varies linearly with time, the graphs of fouling saving and power consumption were plotted against time by curve fitting for different baffle spacing and different fouling thermal conductivity. FS due to heat recovery and the power consumption of shell side fan during operating time $\left(t_{p}\right)$ was found by integrating the Equations obtained by curve fitting.

$$
\begin{aligned}
V_{f} & =\int_{0}^{t_{p}} \dot{V}_{f} d t \quad\left(m^{3}\right) \\
W_{s} & =\int_{0}^{t_{p}} \dot{W}_{s} d t \quad(k W h)
\end{aligned}
$$

\subsection{Cost analysis}

For the specified heat requirement, the energy related costs such as fan power and fuel cost should be known in order to optimize the BS in heat exchanger. Monetary values of the FS and the FPC were calculated by Equations 22 and 23 .

$$
\begin{gathered}
M_{f}=V_{f} F_{n g} \\
M_{w}=W_{T} F_{e}=\left(W_{t}+W_{s}\right) F_{e}
\end{gathered}
$$

where $F_{n g}$ is the price of natural gas per $\mathrm{m}^{3}, F_{e}$ is the price of electric per $\mathrm{kWh}, W_{T}$ is the total power consumption of the shell and tube side fans in $\mathrm{kWh}$.

Monetary saving is the difference between monetary values of the FS and FPC.

$$
M S=M_{f}-M_{w}
$$

By using Equation 22 and 23, the Equation 24 can be written as follows:

$$
\begin{gathered}
M S=F_{e}\left(V_{f} R-W_{T}\right) \\
\frac{M S}{F_{e}}=\left(V_{f} R-W_{T}\right)
\end{gathered}
$$

where, $\mathrm{R}$ is the ratio of $F_{n g}$ to $F_{e}$ and $M S / F_{e}$ is monetary saving per unit price of electricity. 


\section{Results}

Energy and pressure loss analysis of the STHE were carried out under clean and fouled conditions. The calculations were performed for two values of the fouling thermal conductivity $\left(\mathrm{k}_{\mathrm{f} 1}=0.05, \mathrm{k}_{\mathrm{f} 2}=0.1\right.$ $\mathrm{W} / \mathrm{mK}$ ) and five fouling thicknesses in the $0.1-0.5$ mm range when 7,5 and 3 baffles $\left(\mathrm{N}_{\mathrm{b}}\right)$ were used. The results were shown in Table 2 . It can be seen from the Table 2 that fouling affects both the heat recovered and the pressure drop in STHEs. As FT increases, the tube outlet temperature decreases and shell outlet temperature increases while the inlet temperatures are constant. The recovered heat and therefore fuel saving reduces due to the decrease in temperature differences.

It is known that the narrowing of the flow section increases the velocity. Table 2 shows that as FT increases, pressure drop due to increased velocity in shell side and therefore FPC increases. Since tube side fouling was not taken into consideration, the FPC of tube side is the same under clean and fouled conditions. Its values calculated by Equation 18 are
$1.891,1.902$ and $1.907 \mathrm{~kW}$ for $\mathrm{B}=0.58,0.775$ and 1.16 $\mathrm{m}$ respectively.

As the BS increases, the total heat transfer coefficient decreases due to the increase in deviation from crossflow, thereby reducing heat recovery and fuel saving. And also, the pressure loss and therefore FPC reduces as BS increases. It is also seen that FPC decreases at a higher rate than FS as baffle spacing increases.

Figures 4 and 5 show the change of recovered heat and pressure drop in the STHE with the fouling thickness for $\mathrm{k}_{\mathrm{f} 1}$ and $\mathrm{k}_{\mathrm{f} 2}$. The heat resistance in the tube wall increases due to the fouling layer with low thermal conductivity coefficient. At the same FT, the lower heat transfer coefficient causes lower heat recovered. It was seen from Figure 4 that the recovered heat for thermal conductivity of 0.05 $\mathrm{W} / \mathrm{mK}$ decreases faster than for $0.1 \mathrm{~W} / \mathrm{mK}$ as the FT increases.

It was seen from Figure 5 that the effect of fouling layer thermal conductivity coefficient on pressure

Table 2. The results of energy and pressure drop analyses for $B=0.58 / 0.775 / 1.16 \mathrm{~m}$

\begin{tabular}{|c|c|c|c|c|c|c|}
\hline $\begin{array}{l}\text { Thicknes } \\
\text { of fouling } \\
\text { layer } \\
\text { (mm) }\end{array}$ & $\begin{array}{c}\text { Thermal } \\
\text { conductiviy } \\
\text { of fouling } \\
\text { layer } \\
(\mathrm{W} / \mathrm{mK})\end{array}$ & $\begin{array}{c}\text { Tube side } \\
\text { outlet } \\
\text { temperature } \\
\left({ }^{\circ} \mathrm{C}\right)\end{array}$ & $\begin{array}{c}\text { Shell side outlet } \\
\text { temperature } \\
\left({ }^{\circ} \mathrm{C}\right)\end{array}$ & $\begin{array}{l}\text { Overall heat } \\
\text { transfer } \\
\text { coefficients } \\
\left(\mathrm{W} / \mathbf{m}^{2} \mathbf{K}\right)\end{array}$ & $\begin{array}{c}\text { Recovered } \\
\text { heat } \\
(\mathbf{k W})\end{array}$ & $\begin{array}{c}\text { Shell side } \\
\text { pressure loss } \\
\text { (Pa) }\end{array}$ \\
\hline \multirow{3}{*}{\multicolumn{2}{|c|}{ Without fouling }} & 93.41 & 86.81 & 29.93 & 276.9 & 5562 \\
\hline & & 91.43 & 88.79 & 28.10 & 269 & 2812 \\
\hline & & 88.28 & 91.94 & 25.42 & 256.4 & 1084 \\
\hline \multirow{6}{*}{0.1} & \multirow{3}{*}{0.05} & 92.73 & 87.49 & 29.29 & 274.2 & 5593 \\
\hline & & 90.82 & 89.40 & 27.56 & 266.6 & 2829 \\
\hline & & 87.77 & 92.45 & 25.01 & 254.4 & 1091 \\
\hline & \multirow{3}{*}{0.1} & 93.15 & 87.07 & 29.68 & 275.9 & 5596 \\
\hline & & 91.21 & 89.01 & 27.90 & 268.2 & 2830 \\
\hline & & 88.12 & 92.10 & 25.29 & 255.8 & 1091 \\
\hline \multirow{6}{*}{0.2} & \multirow{3}{*}{0.05} & 92.07 & 88.15 & 28.68 & 271.6 & 5625 \\
\hline & & 90.21 & 90.01 & 27.03 & 264.2 & 2845 \\
\hline & & 87.26 & 92.96 & 24.61 & 252.3 & 1097 \\
\hline & \multirow{3}{*}{0.1} & 92.88 & 87.34 & 29.43 & 274.8 & 5630 \\
\hline & & 90.98 & 89.24 & 27.70 & 267.2 & 2848 \\
\hline & & 87.96 & 92.26 & 25.16 & 255.1 & 1098 \\
\hline \multirow{6}{*}{0.3} & \multirow{3}{*}{0.05} & 91.42 & 88.80 & 28.09 & 269 & 5657 \\
\hline & & 89.62 & 90.60 & 26.53 & 261.8 & 2862 \\
\hline & & 86.76 & 93.46 & 24.22 & 250.3 & 1104 \\
\hline & \multirow{3}{*}{0.1} & 92.61 & 87.61 & 29.18 & 273.7 & 5665 \\
\hline & & 90.75 & 89.17 & 27.50 & 266.3 & 2867 \\
\hline & & 87.80 & 92.42 & 25.03 & 254.5 & 1105 \\
\hline \multirow{6}{*}{0.4} & \multirow{3}{*}{0.05} & 90.78 & 89.44 & 27.52 & 266.4 & 5690 \\
\hline & & 89.04 & 91.18 & 26.04 & 259.5 & 2879 \\
\hline & & 86.27 & 93.95 & 23.84 & 248.3 & 1111 \\
\hline & \multirow{3}{*}{0.1} & 92.34 & 87.88 & 28.93 & 272.6 & 5701 \\
\hline & & 90.52 & 89.70 & 27.30 & 265.4 & 2884 \\
\hline & & 87.62 & 92.60 & 24.89 & 253.8 & 1113 \\
\hline \multirow{6}{*}{0.5} & \multirow{3}{*}{0.05} & 90.15 & 90.07 & 26.98 & 263.9 & 5723 \\
\hline & & 88.47 & 91.75 & 25.57 & 257.2 & 2896 \\
\hline & & 85.78 & 94.44 & 23.47 & 246.3 & 1117 \\
\hline & \multirow{3}{*}{0.1} & 92.08 & 88.14 & 28.69 & 271.6 & 5736 \\
\hline & & 90.30 & 89.92 & 27.11 & 264.5 & 2902 \\
\hline & & 87.45 & 92.77 & 24.76 & 253.1 & 1120 \\
\hline
\end{tabular}


drop is not as great as in heat recovery. Because the effect of the heat transfer coefficient on pressure drop is due to the change in fluid density. The effect of velocity on the pressure drop is more than density as seen from Equations 11 and 12. On the other hand the decrease in average fluid density depending on the outlet temperature in shell side tends to reduce the pressure drop. This trend is higher in lower heat transfer coefficients. Therefore the pressure drop for thermal conductivity of $0.1 \mathrm{~W} / \mathrm{mK}$ increases faster than for $0.05 \mathrm{~W} / \mathrm{mK}$ as the FT increases.

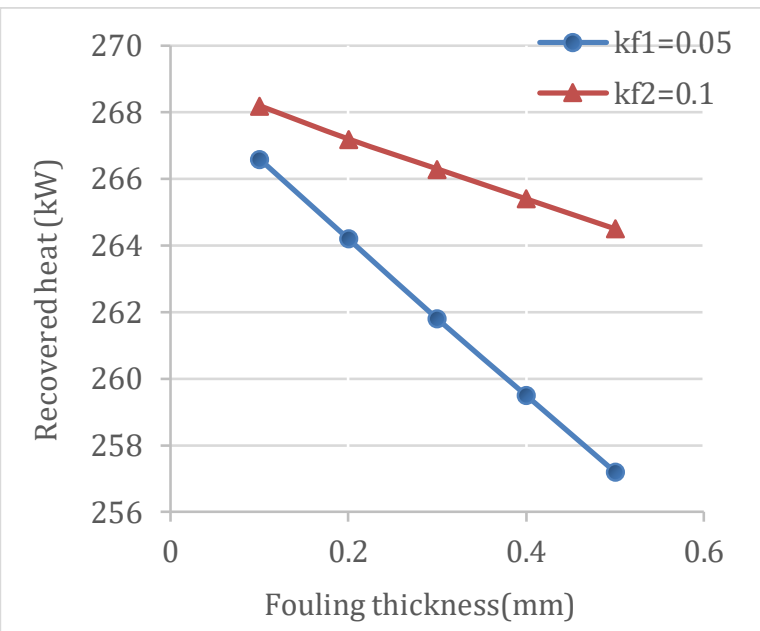

Figure 4. Change of recovered heat with fouling thickness.

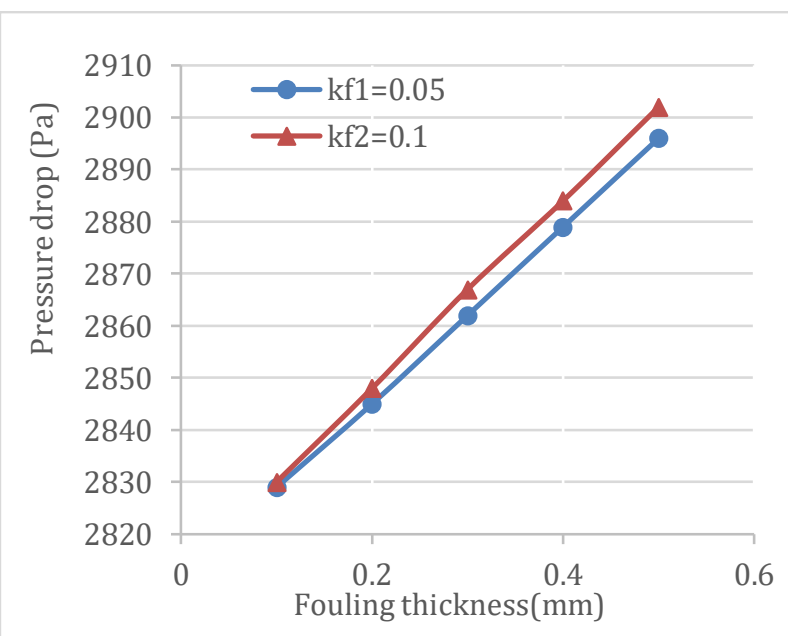

Figure 5. Change of pressure drop with fouling thickness.

The FT on tubes of prototype exchanger reached to about $0.5 \mathrm{~mm}$ within three month (1914 hours). (The operating time of stenter machine in one month is 638 hours). FS due to recovered heat and fan power consumption due to pressure drop were calculated by assuming that fouling thickness varies linearly with time. The graphs of fuel saving and FPC were plotted against time by curve fitting for different BS and different fouling thermal conductivity as shown in Figures (6)-(9).

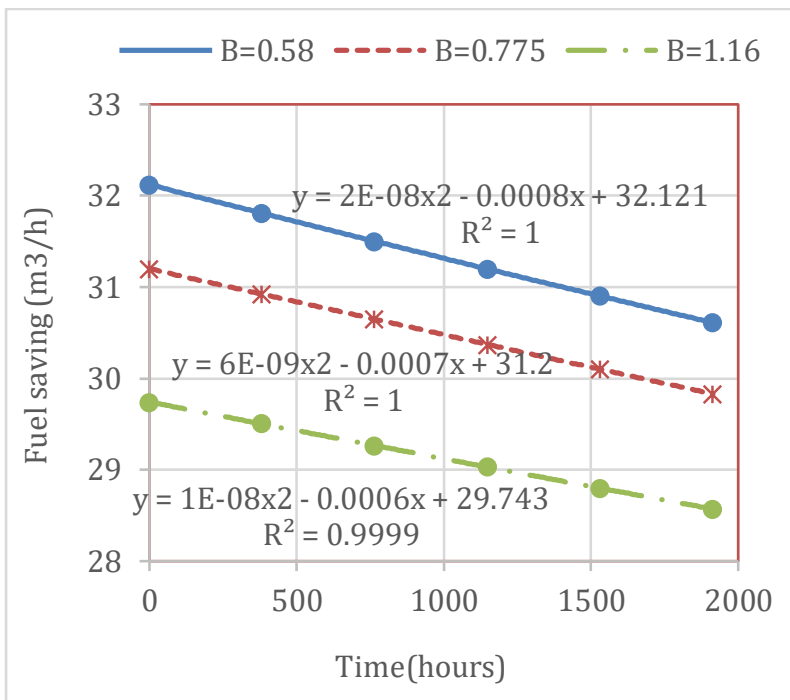

Figure 6. Change of fuel saving with time $\left(\mathrm{k}_{\mathrm{f} 1}=0.05 \mathrm{~W} / \mathrm{mK}\right)$.

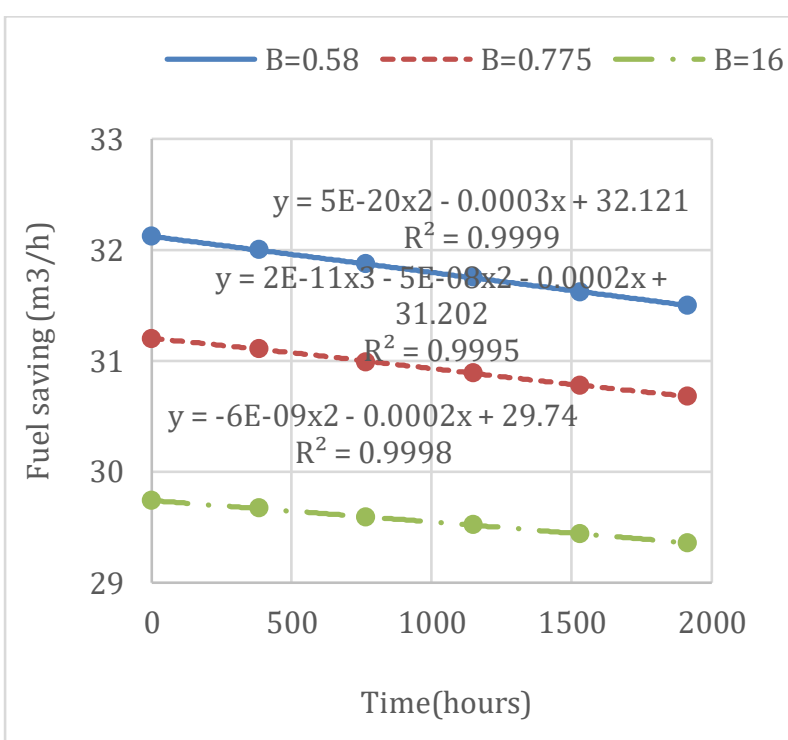

Figure 7. Change of fuel saving with time $\left(\mathrm{k}_{\mathrm{f} 2}=0.1 \mathrm{~W} / \mathrm{mK}\right)$.

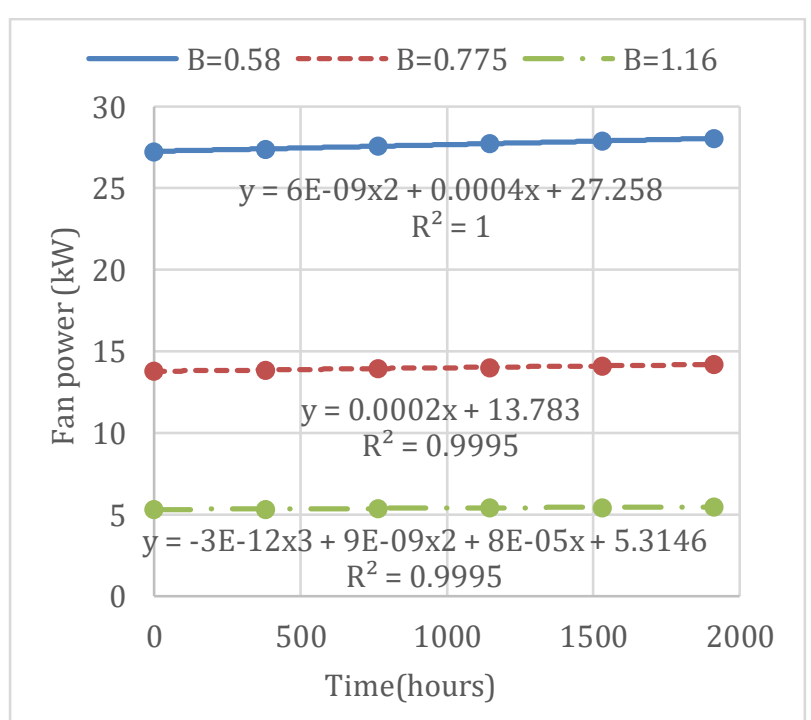

Figure 8. Change of fan power consumption with time $\left(\mathrm{k}_{\mathrm{f} 1}=0.05 \mathrm{~W} / \mathrm{mK}\right)$. 


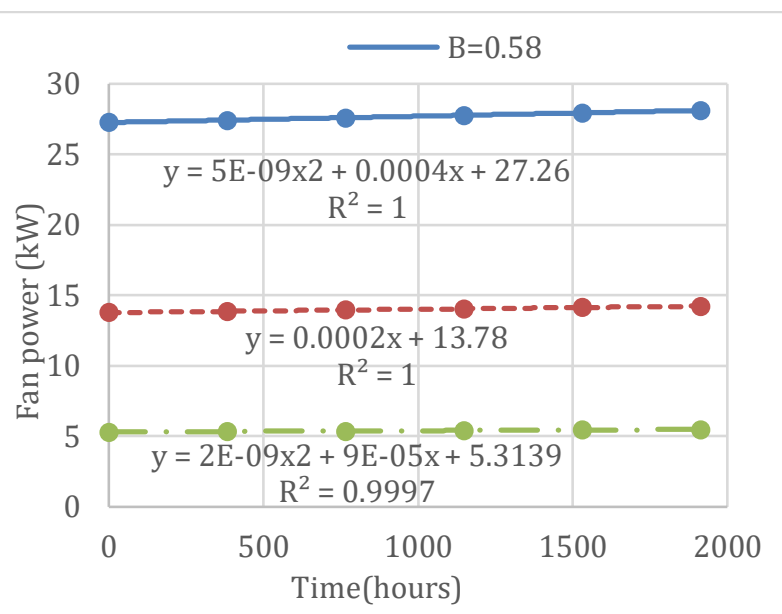

Figure 9. Change of fan power consumption with time $\left(\mathrm{k}_{\mathrm{f} 2}=0.1 \mathrm{~W} / \mathrm{mK}\right)$.

Figures 6 and 7 show the same trend as Figure 4. It was seen from Figure 6 and 7 that as the FT and BS increase, the FS decreases due to the decrease of the recovered heat. The decrease in FS for thermal conductivity of $0.05 \mathrm{~W} / \mathrm{mK}$ is faster than for 0.1 $\mathrm{W} / \mathrm{mK}$ and also for a short BS is faster than for a long one.

Figures 8 and 9 show the same trend as Figure 5. It was seen from Figure 8 and 9 that the FPC increases as the FT increases and decreases as the BS increases depending on pressure loss. The effect of fouling layer thermal conductivity on FPC is not as great as on fuel saving. As the FT increases, the increase in FPC is almost the same for both thermal conductivity but for a short BS increases at a faster rate than for a long one.

Figure 10 shows monetary saving per unit price of electricity versus $\mathrm{R}$ value for the operating time of three months when $k_{f 1}=0.05 \mathrm{~W} / \mathrm{mK}$. As can be seen from Figure 10, monetary saving per price of electricity $\left(M S / F_{e}\right)$ increases as $\mathrm{R}$ value increases for each BS and also optimum BS varies with $R$ value. For $R$ values smaller than 6 , between 6 and 17 and bigger than 17, economic BS were found to be $1.16 \mathrm{~m}, 0.775$ $\mathrm{m}$ and $0.58 \mathrm{~m}$ respectively for $k_{f 1}=0.05 \mathrm{~W} / \mathrm{mK}$.

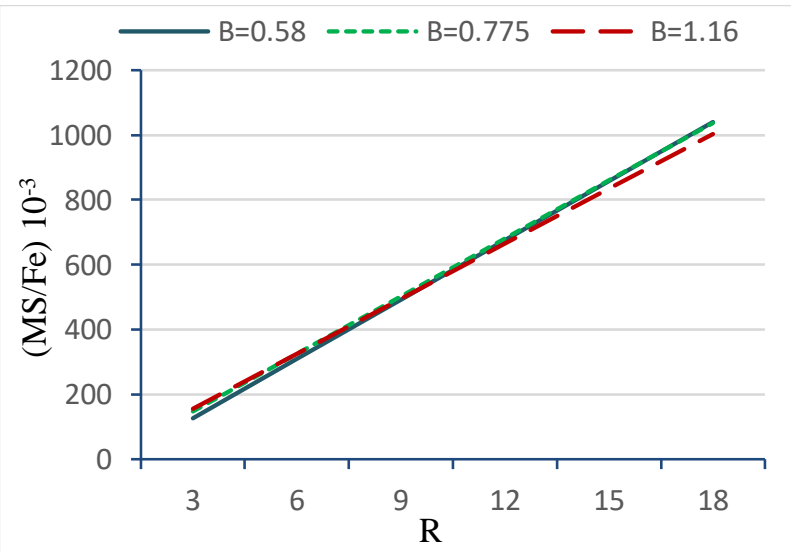

Figure 10. Monetary saving per unit price of electricity versus $R$ value $\left(\mathrm{k}_{\mathrm{f}_{1}}=0.05 \mathrm{~W} / \mathrm{mK}\right)$.
Table 3 shows optimum BS for R values in different fouling conditions. The effect of fouling on BS was seen for only large values of R. For example, for $\mathrm{R}=17$, optimum $\mathrm{BS}$ is $0.58 \mathrm{~m}$ in case of three-month contamination whereas it is $0.775 \mathrm{~m}$ in case of sixmonth contamination. The thermal conductivity coefficient of fouling layer didn't affect optimum BS in case of three-month contamination, but it affected optimum BS in case of six-month contamination for large $\mathrm{R}$ values.

Table 3. Optimum baffle spacing

\begin{tabular}{llllll}
\hline $\begin{array}{l}\text { Baffle } \\
\text { spacing }\end{array}$ & $\begin{array}{l}\text { No } \\
\text { fouling }\end{array}$ & \multicolumn{2}{l}{$\begin{array}{l}\text { Three mounts } \\
\text { operating }\end{array}$} & \multicolumn{2}{l}{$\begin{array}{l}\text { Six mounts } \\
\text { operating }\end{array}$} \\
\cline { 3 - 6 } & & $\mathrm{k}_{\mathrm{f} 1}$ & $\mathrm{k}_{\mathrm{f} 2}$ & $\mathrm{k}_{\mathrm{f} 1}$ & $\mathrm{k}_{\mathrm{f} 2}$ \\
\hline 0.58 & $\mathrm{R} \geq 15$ & $\mathrm{R} \geq 17$ & $\mathrm{R} \geq 17$ & $\mathrm{R} \geq 18$ & $\mathrm{R} \geq 21$ \\
0.775 & $6<\mathrm{R}<15$ & $6<\mathrm{R}<17$ & $5<\mathrm{R}<17$ & $6<\mathrm{R}<18$ & $5<\mathrm{R}<21$ \\
1.16 & $\mathrm{R} \leq 6$ & $\mathrm{R} \leq 6$ & $\mathrm{R} \leq 5$ & $\mathrm{R} \leq 6$ & $\mathrm{R} \leq 5$ \\
\hline
\end{tabular}

In this study, economic BS was determined as $1.16 \mathrm{~m}$ because $R$ value is 3.52 in Turkey based on price of electricity and natural gas obtained from firm invoices as $\mathrm{F}_{\mathrm{e}}=0.21 \mathrm{TL} / \mathrm{kWh}$ and $\mathrm{F}_{\text {ng }} 0.74 \mathrm{TL} / \mathrm{m}^{3}$. Table 4 shows monetary saving as Turkish Lira (TL).

Table 4. Monetary saving for $\mathrm{Fe}=0.21 \mathrm{TL} / \mathrm{kWh}, \mathrm{R}=3.52$

\begin{tabular}{llll}
\hline & \multicolumn{3}{c}{ Monetary saving (TL/three months) } \\
& $\mathrm{B}=0.58$ & $\mathrm{~B}=0.775$ & $\mathrm{~B}=1.16$ \\
\hline $\begin{array}{l}\text { Without } \\
\text { fouling }\end{array}$ & 33777 & 37887 & 39220 \\
\hline $\mathrm{k}_{\mathrm{f} 1}=0.05$ & 32572 & 36882 & 38395 \\
$\mathrm{k}_{\mathrm{f} 2}=0.1$ & 33215 & 37505 & 38903 \\
\hline
\end{tabular}

\section{Discussion and Conclusion}

In this study, the optimum baffle spacing of the segmentally baffled shell and tube exchanger was investigated in clean and fouled conditions. The results show that optimum baffle spacing varies with $R$ value which is the ratio of price of natural gas to that of electricity, but the effect of fouling on the optimum baffle spacing is not significant. Fouling affected optimum baffle spacing for only large $\mathrm{R}$ values. In this study, optimum baffle spacing was determined as $1.16 \mathrm{~m}$ for both dirty and clean condition, because $\mathrm{R}$ is 3.52 in Turkey. The results obtained here are only for the present exchanger. The exchangers of other sizes and configurations should be specifically examined in the future research.

\section{Acknowledgment}

This study is based on a research supported by The Scientific and Technological Research Council of Turkey (TUBITAK, TEYDEB Project Number: 3150652).

\section{References}

[1] Abdelkader, B. A., Zubair, S. M. 2019. The Effect of a Number of Baffles on the Performance of Shell and Tube Heat Exchangers. Heat Transfer Engineering, 40, 39-52. 
[2] Soltan, B. K., Avval, M. S., Damangir, E. 2004. Minimizing Capital and Operating Costs of Sheel and Tube Condensers Using Optimum Baffle Spacing. Applied Thermal Engineering, 24, 28012810.

[3] Li, H., Kottke, V. 1998. Effect of Baffle Spacing on Pressure Drop and Local Heat Transfer in Shell and Tube Heat Exchangers for Staggered Tube Arrangement. Heat Mass Transfer, 41(10), 13031311.

[4] Eryener, D. 2006. Thermoeconomical Optimization of Baffle Spacing for Shell and Tube Heat Exchanger. Energy Conversion and Management, 47, 1478-1489.

[5] Jozaei, A. F., Baheri, A., Hafshejani, M. K., Arad, A. 2012. Optimization of Baffle Spacingon Heat Transfer Pressure Drop and Estimated Price in a Shell and Tube Heat Exchanger. World Applied Sciences Journal, 18(12), 1727-1736.

[6] Wang, F. L., He, Y. L., Tong, Z. X., Tang, S. Z. 2017. Real-time Fouling Characteristics of a Typical Heat Exchanger Used in the Waste Heat Recovery Systems. International Journal of Heat and Mass Transfer 104, 774-786.

[7] Wallhäußer, E., Hussein, M. A., Becker, T. 2012. Detection Methods of Fouling in Heat Exchangers in the Food Industry. Food Control, 27, 1-10.

[8] Kim, W., Cho, Y. I. 2011. Benefit of Filtration in Physical Water Treatment for the Mitigation of Mineral Fouling in Heat Exchangers. International Communications in Heat and Mass Transfer 38, 1008-1013.

[9] Markowski, M., Trafczynski, M., Urbaniec, K. 2013. Identification of the Influence of Fouling on the Heat Recovery in a Network of Shell and Tube Heat Exchangers. Applied Energy, 102, 755-764.

[10] Shen, C., Cirone, C., Yang, L., Jiang, Y.,Wang, X. 2014. Characteristics of Fouling Development in Shell- and - Tube Heat Exhanger: Effects of Velocity and Installation Location. International Journal of Heat and Mass Transfer 77, 439-448.

[11] Bouris, D., Papadakis, G., Bergeles, G. 2001. Numerical Evaluation of Alternate Tube Confirugations for Particle Deposition Rate Reduction in Heat Exchanger Tube Bundles. International Journal of Heat and Fluid Flow, 22, 525-536.

[12] Mavridou, S. G., Bouris, D. G. 2012. Numerical Evaluation of a Heat Exchanger with Inline Tubes of Different size for Reduced Fouling Rates. International Journal of Heat and Mass Transfer 55, 5185-5195.

[13] Han, H., He, Y. A., Tao, W. Q., Li, Y. S. 2014. A Parameter Study of Tube Bundle Heat
Exchangers for Fouling Rate Reduction. International Journal of Heat and Mass Transfer 72, 210-221.

[14] Caputo, A. C., Pelagagge, P. M., Salini, P. 2011. Joint Economic Optimization of Heat Exchanger Design and Maintenance Policy. Applied Thermal Engineering, 31, 1381-1392.

[15] Bell, K. J. 1988. Delawere Method for Shell Side Design. Heat Transfer Equipment Design Hemisphere Publising, 41(10), 145-167.

[16] Taborek, J. 1983. Heat Echangers Design Handbook. Section 3.3. Shell and Tube Heat Exchangers: Single Phase Flow, Hemisphere Publishing, Washington, DC, 992 s.

[17] Karimi Donaa, M. H., Jalaliradb, M. R. 2014. Software Evaluation Via a Study of Deviations in Results of Manual and Computer-Based StepWise Method Calculations for Shell and Tube Heat Exchangers, International Journal of Applied Science and Engineering, 12, 2, 117-126.

[18] Kara, Y. A., Güraras, Ö. 2004. A Computer Program for designing of Shell-and-Tube Heat Exchangers. Applied Thermal Engineering, 24, 1797-1805.

[19] Kakaç, S., Liu H. 2002. Heat Exchangers: Selection Rating and Thermal Design Second Edition. CRC Press Taylor and Francis Group Publishing, Washington, DC, 520s.

[20] Genceli, O. F. 1999. Heat Exchangers, Birsen Publishing, İstanbul, 424 s.

\section{Appendices}

Nomenclatures not defined in the study are given below.

\section{Nomenclatures}

$c_{p} \quad$ specific heat capacity $(\mathrm{kJ} / \mathrm{kgK})$

$F \quad$ logaritmik sıcaklık düzeltme faktörü

$h_{t}, h_{s} \quad$ heat transfer coefficient tube side and shell side $\left(\mathrm{W} / \mathrm{m}^{2} \mathrm{~K}\right)$

$h_{s}{ }^{\prime} \quad$ heat transfer coefficient for pure crossflow in an ideal tube bundle $\left(\mathrm{W} / \mathrm{m}^{2} \mathrm{~K}\right)$

$K \quad$ overall heat transfer coefficient, $\left(\mathrm{W} / \mathrm{m}^{2} \mathrm{~K}\right)$

$k_{\text {tube, }} k_{f}$ thermal conductivity coefficient of tube wall and fouling thickness $(\mathrm{W} / \mathrm{mK})$

$M_{f} \quad$ fuel cost related to fuel saving

$M_{w} \quad$ energy cost related to power consumption

$\dot{m} \quad$ mass flow rate $(\mathrm{kg} / \mathrm{s})$

$\mathrm{Pr} \quad$ Prandlt number

$\dot{V}_{s} \quad$ shell and tube side volume flow rate $\left(\mathrm{m}^{3} / \mathrm{s}\right)$

$\rho \quad$ density $\left(\mathrm{kg} / \mathrm{m}^{3}\right)$

$\mu \quad$ dynamic viscosity $(\mathrm{kg} / \mathrm{ms})$

$\Delta T_{m} \quad$ logaritmic temperature difference 